\title{
The Use of Reference in the Text on Tourism Travel Agency Website
}

\author{
I Gusti Ngurah Adi Rajistha ${ }^{1}$, Dewa Ayu Kadek Claria ${ }^{2}$ \\ \{rajistha@warmadewa.ac.id ${ }^{1}$, claria@warmadewa.ac.id²
}

Universitas Warmadewa, Denpasar, Bali

\begin{abstract}
Many tour packages can not deliver their content to the maximum due to language barrier. In general, language is critical in forming the text of tour packages. This study examines the construction of text on the tour package in terms of grammatical cohesion and reference. It aim to serve as reference for further studies on the influence of language in website optimization. Importantly, this study uses a descriptive qualitative approach. The data source used is the text of a tour package in *txt format that is processed computationally with the antconc program. The corpus of the data collected is classified according to the type of reference, while the grammatical cohesion theory by Haliday and Hasan (1976) was used for analysis. Also, the outcome of the data analysis were presented both formally and informally. The results showed that references greatly influenced the text to keep focused on the intended subject. The references applied were more focused on the text readers. Moreover, the use of non-neutral demonstrative references might confuse the the intended in readers' perspective.
\end{abstract}

Keywords: references, travel text, travel agency website, bounce rate

acuan, teks wisata, website biro perjalanan wisata

\section{Pendahuluan}

Pariwisata merupakan bagian yang tidak terpisahkan dari kehidupan masyarakat Bali. Budaya dan keindahan alam di Bali menjadi daya tarik tersendiri bagi para wisatawan yang berkunjung ke Bali. Tercatat jumlah kunjungan wisatawan mancanegara ke Bali pada bulan Januari 2019 adalah sebanyak 456.218 kunjungan atau naik sebesar 27,41\% dibandingkan dengan kunjungan pada Januari 2018 [1]. Tingginya minat kunjungan ke Bali menyebabkan munculannya banyak pelaku wisata di berbagai sektor, tidak terkecuali di sektor biro perjalanan wisata. Hal ini menyebabkan munculnya aktivitas promosi untuk mendukung keberlanjutan di sektor tersebut. Ada beberapa cara yang sesuai untuk strategi promosi pariwisata yaitu melalui buku pedoman, iklan pada internet, TV, brosur, dan koran [2]. 
Penggunaan media sosial dan website untuk mempromosikan produk jasa ini dapat dikatakan cara yang cukup efektif mengingat tingginya pengguna media sosial dan internet pada saat ini. Tercatat sebanyak 3.484 milyar pengguna media sosial dan 4.388 milyar pengguna internet dari populasi dunia sebesar 7.676 milyar, ini menunjukkan bahwa hampir setengah penduduk dunia merupakan pengguna aktif media sosial dan sudah lebih dari setengah penduduk dunia mengenal internet [3]. Dengan demikian promosi melalui media online merupakan pilihan yang tepat untuk mempromosikan usaha di sektor biro perjalanan.

Tingginya tingkat persaingan di dunia maya untuk mempromosikan produk jasa perjalanan melalui media sosial maupun website harus diikuti dengan kualitas promosi produk yang bertaraf internasional dengan menggunakan Bahasa Inggris yang baik sehingga informasi dapat tersampaikan secara jelas. Penggunaan Bahasa Inggris pada website tidak hanya koheren antar kalimatnya, tetapi juga harus koheren antar bagian pada website tersebut.

Penyampian informasi secara details, runtun, singkat, padat, jelas dan menarik memberikan pengalaman membaca yang positif bagi pengunjung suatu website. Dalam hal ini, teks harus koheren secara gramatikal. Oleh karena itu, pemilik teks harus mampu membuat teks yang memiliki makna yang jelas, situated meaning atau cultural model [4]. Selain itu melakukan evaluasi terhadap teks yang dibuat merupakan cara peningkatan kualitas teks [5].

Sebagai media elektronik, website tidak hanya terdiri dari kalimat-kalimat tetapi juga gambar, audio, dan video. Dalam hal ini, kalimat-kalimat yang digunakan tidak hanya saling berhubungan satu dengan yang lainnya tetapi juga berhubungan dengan bagian website itu sendiri yaitu berhubungan secara visual [6]. Dengan demikian, website sebagai sarana iklan harus memiliki teks yang koheren sehingga subjek yang dibicarakan menjadi semakin fokus dan memberikan makna persuasif [7]. Website memiliki beberapa bagian penting dalam mengoptimalkan indeksasi dari mesin pencari, seperti google.com, yahoo.com, bing.com ataupun mesin pencari yang lainnya. Untuk memaksimalkan hal tersebut, penggunaan bahasa merupakan bagian penting dalam suatu website. Bahasa digunakan dalam bagian eksternal dan internal dari suatu website. Dengan demikian, bahasa dapat dikatakan sebagai salah satu syarat penting dalam suatu website. Dalam hal ini, teks pada website harus tetap memperhatikan unsur kohesi baik gramatikal maupun leksikal. Secara leksikal, kohesi leksikal mendukung penggunaan keywords pada tour website melalui relasi leksikal yang ditemukan pada elemen website seperti pada website title, meta keyword, meta description, heading, content, links, dan image titles [8].Teks yang koheren secara leksikal memang sangat mendukung optimasi suatu website, namun pengalaman membaca yang positif yang diperoleh dari koherensi secara gramatikal juga merupakan bagian yang penting. Penelitian ini memberikan gambaran tentang kohesi gramatikal teks paket perjalanan wisata, khususnya penerapan acuan. Pengalaman membaca yang positif merupakan langkah awal untuk menarik minat wisatawan untuk memesan jasa perjalanan wisata pada website tersebut.

\section{Metode}

Sumber data ditentukan dengan menghubungi pemilik website yang bersedia websitenya digunakan sebagai sumber data. Penelitian ini merupakan penelitian deskriptif kualitatif dengan menggunakan sumber data teks paket perjalanan wisata. Jenis data yang digunakan merupakan kalimat-kalimat pada teks paket perjalanan wisata. Dalam website yang digunakan terdapat 
beberapa bagian yang dapat dianalisis, namun penelitian ini hanya menggunakan bagian paket perjalanan wisata sebagai sumber data, dengan menggunakan 41 teks yang dikategorikan sebagai paket perjalanan wisata. Instrumen penelitian yang digunakan adalah program antconc untuk mengumpulkan kopus data secara komputasi untuk mempermudah dalam memperoleh data dan klasifikasi data. Dengan demikian, data akan diperoleh dengan waktu yang lebih cepat dibandingkan dengan cara manual. Pengaplikasian ruang penyimpanan berbasis cloud juga akan diterapkan dalam penelitian ini untuk pengorganisasian, sinkronisasi, dan pembagian tugas serta data. Data dikumpulkan dengan mangambil seluruh paket perjalanan wisata pada website yang akan digunakan sebagai sumber data dengan bantuan pengembang website (web developer). Setiap teks paket perjalanan wisata akan dijadikan file dengan format *.txt untuk mempermudah pengolahan data menggunakan program antconc. Data yang telah dikumpulkan dan diklasifikasi dianalisis menggunakan teori kohesi gramatikal oleh Halliday dan Hassan (1976). Hasil penelitian disajikan secara formal dengan menggunakan tabel dan secara informal untuk memudahkan dalam pendeskripsian hasil analisis.

\section{Hasil Dan Pembahasan}

\subsection{Hasil}

Kohesi gramatikal adalah salah satu sudut pandang yang menjelaskan keterikatan dan keterkaitan elemen-elemen dalam teks dilihat dari sisi gramatikal. Kohesi gramatikal dapat dikategorikan menjadi empat yaitu: acuan, substitusi, elipsis dan konjungsi. Keempat jenis kohesi gramatikal ini menuntun pembaca untuk dapat memahami isi teks dengan lebih mudah. Melalui teks yang koheren, pembaca tentu dapat memahami isi teks dengan lebih mudah dan tidak menimbulkan makna yang lain. Teks paket perjalanan wisata harus memberikan pengalaman membaca yang positif. Pengalaman pembaca yang positif ini merupakan nilai penting dalam pengelolaan website. Salah satu dampak positifnya adalah tidak terjadinya lompatan (bounce) yang dilakukan oleh pembaca website. Bounce sendiri yang dihitung dengan bounce rate menunjukan seberapa setia pembaca membaca teks yang disajikan. Ketika terjadi lompatan atau perpindahan ke website lain tentu hal tersebut akan meningkatkan bounce rate yang memberikan kesan negative terhadap website tersebut. Oleh karena itu, teks yang koheren secara gramatikal adalah syarat penting untuk meningkatkan pengalaman pembaca dan meningkatkan kesetiaan dalam membaca teks website tersebut sehingga meningkatkan kemungkinan adanya pemesanan yang dilakukan melalui website tersebut.

Salah satu kohesi gramatikal yang penting adalah acuan. Acuan pada suatu teks sangat penting karena acuan memberikan hubungan semantis antar kalimat yang membentuk teks tersebut. Secara umum acuan dapat dikategorikan menjadi tiga yaitu acuan personal, acuan demonstratif, dan acuan komparatif. Penggunaan ketiga jenis acuan dapat memberikan nuansa koheren pada teks apabila digunakan dengan tepat. Penggunaan acuan yang tidak tepat dapat menimbulkan kesalahpahaman penerimaan makna atau maksud teks sehingga menurunkan tingkat kepercayaan pembaca. Dengan kata lain, acuan merupakan salah satu bagian penting dalam membangun teks yang koheren. Tabel 1 berikut ini menunjukkan ketiga jenis acuan yang diaplikasikan pada teks paket perjalanan wisata.

Table 1 Acuan yang Ditemukan dalam Teks 


\begin{tabular}{llll}
\hline No. & Jenis Acuan & Pengisi Acuan & Acuan yang Digunakan \\
\hline 1. & Acuan personal & Pronomina & you, we, they \\
& & Adjektiva posesif & your, our, their \\
2. & Acuan & Pronomina & this \\
& demonstratif & Adjektiva demonstratif & this, these, those \\
& Adverbia & here, there \\
3. & Acuan komparatif & Adjektiva & same, different \\
& & Adjektiva komparatif & more relaxed and comfortable, happier, \\
& & braver \\
\hline
\end{tabular}

Penelitian ini menemukan bahwa ada beberapa isu yang berkaitan dengan acuan yang diterapkan dalam teks paket perjalanan wisata. Isu yang pertama adalah penggunaan acuan personal yang mengacu pada nomina yang memiliki jumlah yang berbeda. Dengan kata lain, dapat dinyatakan bahwa pronomina yang digunakan tidak sesuai secara jumlah dengan nomina yang diacu. Hal ini jelas tidak menunjukkan koherensi antara nomina yang diacu dengan pronomina yang mengacunya. Isu yang kedua adalah penggunaan acuan demonstratif yang memberikan perbedaan interpretasi jarak antara nomina yang diacu dan acuan demonstratif yang digunakan. Penggunaan acuan demonstratif seperti ini seolah-olah memberikan kesan bahwa pembaca memiliki jarak yang dekat dengan nomina yang dimaksud. Hal ini tentu memberikan kesan kedekatan apabila pembaca mengetahui nomina yang dimaksud, namun hal ini juga mengaburkan maksud penulis jika pembaca tidak memiliki latar belakang pengetahuan yang sama.

Berdasarkan isu-isu tersebut, ada beberapa langkah yang dapat diterapkan untuk menjaga koherensi antar kalimat, khususnya dalam penggunaan acuan:

1. Memastikan jumlah nomina yang diacu, sehingga pronomina yang dipilih dapat mewakili sekaligus mengacu pada nomina tersebut.

2. Memfokuskan teks yang disampaikan pada pembaca bukan pembuat teks, sehingga perbedaan interpretasi jarak dapat dihilangkan.

3. Menggunakan acuan demonstratif yang bersifat netral yaitu artikel 'the' juga dapat menghilangkan perbedaan interpretasi jarak.

\subsection{Pembahasan}

\subsubsection{Acuan Personal}

Acuan personal memberikan kesan konsistensi penggunaan pronomina pada teks. Dengan konsistensi penggunaan pronomina pada teks jelas pembaca akan mengetahui siapa yang dimaksud oleh pronomina tersebut. Oleh karena itu, kejelasan penggunaan pronomina adalah hal yang sangat penting untuk memberikan kesan positif dalam membaca. Seperti yang dijelaskan sebelumnya bahwa kesan positif pembaca merupakan hal yang penting dalam pengelolaan website. Acuan personal yang tepat merupakan salah satu cara untuk meningkatkan kesan positif pembaca. Tersedianya makna yang jelas yang mengacu pada pronomina tertentu dapat meningkatkan kepercayaan pengunjung website/pembaca teks pada website tersebut. 
Pentingnya makna yang koheren telah disadari pemilik website, meskipun ada beberapa pronomina yang mengaju pada nomina yang memiliki jumlah yang berbeda. Berdasarkan data yang ditemukan, berikut ini merupakan contoh-contoh penggunaan acuan personal pada teks paket perjalanan wisata yang ditemukan pada website tersebut.

1. After enjoying your activities and holidays on Nusa Lembongan, you will be invited back to Nusa Lembongan harbor to return to Sanur beach. [10]

2. If not, we have a special offer for you, which is a BIG DISCOUNT for the Bali Rafting Adventure package. [11]

3. While enjoying the beautiful natural scenery at Kintamani, we will invite you to lunch at one of the restaurants in Penelokan village. Our next destination is Coffee Plantation Bali, located in the Temen village. [12]

4. Arriving at Turtle Island Tanjung Benoa, you can see many turtles here. They are cultivated to keep the population from extinction. [13]

5. From Tegalalang Rice Terrace we will go to Ubud Monkey Forest to see the herd of monkeys and their behavior. [14]

Data (1) menunjukan penggunaan pronomina you yang diacu sebelumnya dengan penggunaan your. Pronomina you mengacu langsung kepada pembaca/pelanggan/pengunjung website tersebut. Hal ini diterapkan oleh pemilik website untuk mendekatkan konten yang ingin disampaikan dengan pembacanya. Tentu hal ini merupakan startegi dasar untuk menarik minat pengunjung website tersebut. Pronomina you ini diacu oleh adjektiva posesif your. Namun jika diperhatikan kembali, baik pronomina you ataupun adjektiva posesif your pada dasarnya mengacu ke luar teks yaitu mengacu ke pembaca/pengunjung website biro perjalanan tersebut. Dengan penggunaan pronomina you ini, pemilik website mendekatkan teks paket perjalanan wisata yang dimilikinya dengan pembaca/pengunjung websitenya.

Hal yang serupa juga ditemukan pada contoh (2). Pada contoh ini, pemilik website menggunakan pronomina we. Berdasarkan konteks dari teks yang disajikan. Pronomina ini juga mengacu ke luar teks. Acuan konkret tidak disediakan di dalam teks. Namun berdasarkan konteks pada teks tersebut, dapat diketahui bahwa pronomina tersebut mengacu kepada pemilik teks beserta koleganya. Berbeda halnya jika pronomina tersebut dilihat konteksnya dalam satu website, ada kemungkinan bahwa pemilik website dan koleganya memiliki halaman tersendiri untuk menjelaskan identitas mereka. Oleh karena itu, pandangan tentang pronomina yang memiliki makna acuan keluar hanya berdasarkan konteks pada teks, bukan konteks dalam satu website.

Kasus yang sedikit unik dapat dilihat pada contoh (3). Pada contoh ini dapat dilihat adanya penggunaan pronomina we dan adjektiva posesif our. Jika diperhatikan dengan jelas, pronomina we dan adjektiva posesif our mengacu pada nomina-nomina yang berbeda. Penggunaan pronomina we di sini mengacu ke pemilik website dan koleganya sedangkan adjektiva posesif our pada kalimat tersebut mengacu pada pemilik website dan pengunjung/pembaca teks tersebut. Berdasarkan konteks, hal tersebut jelas mudah dipahami, meskipun mungkin terjadi sedikit kesalahpahaman makna yang diterima. Hal ini tentu perlu menjadi pertimbangan untuk teks-teks yang akan dibuat selanjutnya.

Penggunaan pronomina they pada contoh (4) menunjukan acuan dalam teks. Pronomina they ini mengacu pada nomina turtles yang telah disebutkan sebelumnya. Dengan demikian pembaca 
mengetahui dengan jelas siapa they yang dimaksud pada teks tersebut. Penggunaan pronomina yang tepat juga sangat mempengaruhi koherensi pada teks tersebut. Pada dasarnya untuk mengacu pada nomina selain manusia, pemilik bias saja menggunakan pronomina it. Namun pronomina tersebut dipandang tidak sesuai dengan nomina yang dijelaskan. Pronomina tersebut dipilih berdasarkan jumlah nomina yang diacu. Pada contoh ini jelas nomina yang diacu berjumlah lebih dari satu sehingga pronomina yang sesuai adalah pronomina yang dapat menyatakan makna jamak. Jadi keselaran pemilihan pronomina merupakan cara yang penting untuk menjaga koherensi teks.

Sama halnya dengan adjektiva posesif yang digunakan pada contoh (5). Adjektiva their pada contoh ini mengacu pada nomina monkeys yang mendahuluinya. Pemahaman pembaca akan menjadi jelas dengan pemilihan pronomina yang sesuai. Seperti halnya pada contoh sebelumnya, pada contoh ini pemilik website juga menerapkan konsep yang sama. Penggunaan pronomina sangat disesuaikan dengan jumlah nomina yang diacu. Hal ini tentu mempermudah pembaca/pengunjung website untuk memastikan makna dari acuan yang dimaksudkan. Keselarasan jumlah merupakan kunci dalam pemilihan pronomina yang tepat, sehingga ini dapat dikatakan memberikan dampak positif bagi pembaca/pengunjung website terutama dari segi konten dari website tersebut.

Strategi-strategi yang diterapkan oleh pemilik website untuk memberikan pengalaman membaca yang positif melalui acuan personal adalah dengan memperhatikan jumlah nomina yang akan diacu, sehingga pemilihan pronomina dapat disesuaikan. Selain itu, pemilik website juga menerapkan acuan ke luar teks yaitu mengarah langsung ke pembaca/pengunjung website. Hal ini tentu memberikan kesan positif, sehingga deskripsi-deskripsi yang tidak dibutuhkan bisa dihindari. Misalkan penggunaan kata tourist atau visitor yang memberikan kesan yang deskriptif dibandingkan kesan positif bagi pengunjung/pembaca teks pada website tersebut.

\subsubsection{Acuan Demonstratif}

Penggunaan acuan personal memang mendominasi teks pada paket biro perjalanan wisata dalam website tersebut, namun pemilik website juga menerapkan acuan demonstratif pada teksteksnya. Tentu penggunaan ini bukan tanpa tujuan. Website biro perjalanan wisata tentu memiliki kolokasi dengan nomina-nomina seperti destinasi-destinasi wisata, fasilitas perjalanan, biaya, lama perjalanan, dan lain sebagainya. Penggunaan jenis acuan ini akan mengarahkan pembaca/pengunjung website ke nomina tempat yang dimaksud, sehingga jelas dapat membantu pemahaman pembaca/pengunjung website.

Berdasarkan data yang ditemukan, ada beberapa perbedaan sudut pandang yang muncul melalui penggunaan acuan ini. Berikut ini adalah data-data yang ditemukan pada teks paket perjalanan wisata tersebut:

1. This is a new and interesting activity that you can do in Bali. [15]

2. Formerly Kerta Gosa was used as a place of negotiation for the authorities and as a place of royal court. In this destination, you can see ancient buildings with Balinese architecture. [16]

3. We have two places to do Elephant Ride activities, namely at Bali Elephant Camp Carangsari or at Bali Bakas Elephant Ride. Both of these places are favorite places to do elephant ride activities in Bali. [17] 
4. Pickup area: Nusa Dua, Jimbaran, Kuta, Uluwatu, Seminyak, Canggu, Sanur or Ubud. If you are not in one of those areas please don't hesitate to contact us to make a negotiation. [18]

5. This hot spring is called Banjar Hot Spring or Banjar Natural Hot Spring. You can soak and relax your body here. [19]

6. We will always follow you with the private car that you ordered along the way from the starting point to the finish point of Kintamani Cycling activities. So you do not have to worry if you feel that you are not strong enough to continue Kintamani Cycling activities, because we are always there for you. [20]

Seperti yang telah dijelaskan sebelumnya bahwa acuan demonstratif merupakan bentuk penunjuk verbal yang digunakan untuk mengidentifikasi partisipan dan lokasi acuan. Pada data (1), this merupakan acuan demonstratif jenis selective. Demonstratif tersebut mengidentifikasi lokasi acuan yang dekat dengan jumlah partisipan sebanyak satu partisipan. Dalam hal ini, demonstratif tersebut digunakan untuk menyatakan acuan pada paket perjalanan wisata yang sedang dibaca, Activity Bali Aero Fly Station (Sky Diving). Pada data ini, acuan demonstratif yang digunakan adalah sebagai head, sehingga demonstratif ini jelas mengacu pada paket perjalanan yang sedang dibaca.

Pada data (2), acuan yang digunakan adalah this, namun pada data ini this tidak berkedudukan sebagai head melainkan sebagai determiner. Dalam hal ini, this menunjukkan destination, dan memberikan acuan pada nama tempat yang telah dijelaskan sebelumnya, Kerta Gosa. Berdasarkan kedua contoh yang telah dibahas, this dapat menduduki posisi head ataupun determiner. Penggunaan this pada data ini menimbulkan perbedaan interpretasi jarak antara pembaca dengan nomina yang dimodifikasi oleh this. Kalimat tersebut menjelaskan bahwa lokasi pembaca dan nomina yang dimaksud adalah dekat. Namun jika dilihat dari tujuan website untuk mempromosikan paket perjalanannya secara global maka penggunaan artikel the lebih memberikan kesan jarak yang netral dibandingkan dengan menggunakan adjektiva demonstratif this ini.

Data (3) dan (4) menunjukkan penggunaan acuan demonstratif jamak sebagai determiner. Pada data (3), these berfungsi sebagai determiner yang menunjukkan places, sehingga frasa these places tersebut mengacu pada Bali Elephant Camp Carangsari dan Bali Bakas Elephant Ride yang telah dijelaskan sebelumnya. Sama halnya dengan data (4), penggunaan those bertujuan untuk memberikan acuan pada Nusa Dua, Jimbaran, Kuta, Uluwatu, Seminyak, Canggu, Sanur dan Ubud. Perbedaan penggunaan acuan demonstratif tersebut terletak pada acuan jarak antara partisipan dan pembaca teks. These digunakan untuk memberikan acuan yang dekat sedangkan those digunakan untu memberikan acuan yang jauh, dan kedua demonstratif tersebut merupakan dalam bentuk jamak. Pada data (3) jelas yang dimaksud oleh pembuat teks merupakan nama-nama tempat yang sebelumnya telah disebutkan, sehingga pembuat teks menggunakan acuan yang mengacu pada partisipan yang dekat. Namun pada data (4), pembuat teks lebih memilih menggunakan penanda acuan yang memberikan makna acuan yang mengacu pada partisipan yang jauh. Berdasarkan sudut pandang pembaca, harusnya kedua data tersebut menggunakan penanda acuan those. Namun data (3) menggunakan sebaliknya, these. Hal ini dapat dipahami melalui perspektif pembuat teks, yaitu tempat yang disebutkan di dalam teks, sehingga pembuat teks menggunakan acuan dekat untuk memberikan acuan pada kedua tempat tersebut. Sama halnya dengan data (2), penggunaan acuan demonstratif yang bersifat netral lebih dianjurkan pada kalimat-kalimat tersebut. Pada data (5) dan (6), here dan there digunakan untuk memberikan acuan lokasi dengan skala dekat dan jauh. Kedua acuan ini mengacu pada lokasi 
dari proses dalam suatu ruang dan waktu dan tidak mengacu pada lokasi dari orang atau objek yang terlibat dalam proses tersebut. Pada data (5), here memberikan acuan pada lokasi yang telah disebutkan sebelumnya berdasarkan konteks teks yang disajikan, Banjar Hot Spring atau Banjar Natural Hot Spring. Acuan tersebut jelas menunjukan tempat yang dimaksud dengan here tidak berkaitan dengan pembaca teks, namun berhubungan dengan kalimat sebelumnya. Berbeda dengan data (6), pemilik website lebih memilih menggunakan there untuk menunjukkan acuan dari lokasi yang dimaksud, the way from the starting point to the finish point of Kintamani Cycling activities. Penggunaan acuan tersebut memberikan gambaran bahwa there disini digunakan untuk menunjukan acuan lokasi yang jauh. Dalam hal ini jelas ada perbedaan sudut pandang antara data (5) dan data (6). Data (5) memberikan sudut pandang dimana seolah-olah pemilik website dan pembaca teks berada pada lokasi yang sama. Dalam hal ini pemilik website memberikan gambaran abstrak tentang rencana perjalanan dan mengajak pembaca untuk seolah-olah membayangkan perjalanan tersebut. Di lain sisi, data (6) memberikan sudut pandang yang berbeda. Pemilik website dan pembaca teks berada pada lokasi yang jauh dari lokasi yang dimaksud pada teks tersebut. Permasalahan ini juga dapat dihilangkan melalui penggunaan acuan demonstratif yang bersifat netral.

\subsubsection{Acuan Komparatif}

Jenis ini memberikan acuan dengan cara perbandingan (comparison) baik yang bersifat umum maupun yang bersifat khusus. Acuan perbandingan yang bersifat umum secara sederhana dapat digambarkan melalui perbandingan yang menyatakan kemiripan ataupun perbedaan sedangkan yang bersifat khusus dapat dikatakan sebagai acuan perbandingan yang berkaitan dengan kualitas dan kuantitas. Berikut ini adalah beberapa data yang ditemukan dalam website:

1. Packages are ordered 1 day before the activity is carried out. If ordering on the same day as the activity is carried out then you need to confirm directly to us (needed). [21]

2. Taman Ayun Temple and Tanah Lot Temple are two temples that have historical value and uniqueness that make this temple different from thousands of temples in Bali. [22]

3. With Balinese aromatherapy, your body will feel more relaxed and comfortable. [23]

4. We guarantee that you will be happier than before, you will be braver than before, and you will book this package several times. [15]

Penanda acuan perbandingan pada data (1) adalah same. Dengan demikian, acuan perbandingan yang dimaksud bersifat umum karena berhubungan dengan kesamaan atau kemiripan. Same disini merupakan modifier yang diisi oleh adjektiva. Oleh karena itu, same memberikan makna acuan perbandingan pada nomina yang dijelaskan, day. Pada data ini dapat dilihat bahwa yang dibandingkan pada kalimat tersebut adalah hari ketika seseorang melakukan pemesanan dan hari ketika perjalanan itu dilaksanakan.

Data (2) menunjukkan penggunaan adjektiva different sebagai acuan perbandingan. Jenis perbandingan yang dinyatakan oleh adjektiva ini masih bersifat umum seperti halnya data (1). Acuan perbandingan ini memberikan makna ketidaksamaan. Adapun yang dibandingkan pada data ini adalah Taman Ayun Temple dan Tanah Lot Temple dengan thousands of temples in Bali. Konsep dasar acuan perbandingan ini adalah suatu hal yang akan dibandingkan tentu mengacu pada hal lain yang digunakan sebagai pembanding.

Pada data (3) menunjukkan penggunaan penanda acuan perbandingan yang bersifat khusus yaitu menyatakan kualitas. Penggunaan adverbia more sebagai penanda komparatif yang digabungkan dengan adjectiva relaxed dan comfortable membutuhkan acuan perbandingan. 
Adapun yang dibandingkan pada kalimat tersebut adalah kualitas kondisi badan ketika menggunakan aroma terapi dan ketika belum menggunakan aroma terapi. Meskipun pada kalimat tersebut tidak ditampilkan secara eksplisit, namun makna perbandingan jelas dapat diketahui melalui penggunaan adverbia more tersebut.

Selain menggunakan adverbial more, acuan perbandingan dapat juga menggunakan adjectiva komparatif seperti pada data (4). Penggunaan adjectiva comparative happier dan braver dapat digunakan untuk menyatakan acuan perbandingan. Acuan perbandingan tersebut bersifat khusus yang juga menyatakan kualitas. Jelas bahwa hal yang dibandingkan pada kalimat tersebut adalah kondisi pembaca teks apabila telah memesan paket wisata tersebut. Dengan kata lain ada dua kondisi yang dibandingkan dengan menggunakan acuan perbandingan tersebut yaitu kondisi sebelum memesan atau melakukan kegiatan tersebut dan kondisi setelah melakukan kegiatan tersebut.

Berdasarkan penggunaan acuan komparatif pada teks paket perjalanan wisata dapat disimpulkan bahwa pemilik website membandingkan kondisi tanpa menyinggung penyedia jasa perjalanan wisata yang lain. Dalam hal ini, perbandingan yang dibuat hanya bersifat internal dan melibatkan pembaca teks sebagai objek perbandingan secara kualitas.

\section{Kesimpulan}

Berdasarkan penelitian yang telah dilakukan dapat disimpulkan bahwa acuan merupakan bagian dari kohesi gramatikal yang memberikan fokus terhadap subjek yang dijelaskan. Penggunaan acuan yang tepat secara jumlah dan tepat dalam mengacu pada orang atau benda yang dimaksud merupakan hal yang mutlak dalam membangun koherensi. Penggunaan acuan juga dipengaruhi oleh konteks dan sudut pandang pembuat teks, namun perlu diperhatikan bahwa perbedaan sudut pandang yang menjelaskan tentang jarak pembaca dengan nomina yang diacu juga merupakan bagian dari koherensi. Dalam hal ini, acuan demonstratif, khusunya penggunaan this, that, these dan those, dapat digantikan dengan menggunakan acuan demonstratif yang bersifat netral, the.

\section{References}

[1] B. P. S. P. Bali, "Perkembangan pariwisata Bali Januari 2019," 18/03/51/Th. XIII, 2019.

[2] H. Salehi and M. Farahbakhsh, "Tourism advertisement management and efective tools in tourism industry," Int. J. Geogr. Geol., vol. 3, no. 10, pp. 124-134, 2014.

[3] S. Kemp, "Digital 2019: Global internet use accelerates," wearesocial.com, 2019. .

[4] J. P. Gee, An Introduction to Discourse Analysis. New York: Routledge, 2001.

[5] M. Bednarek, Evaluation in Media Discourse. New York: Continuum, 2006.

[6] A. Schiller, "Aspects of cohesion in web site translation: A translator's perspective," Dublin City University, 2008.

[7] A. Flergin, "Language of persuasion: A discourse approach to advertising language," Res. $J$. Recent Sci., vol. 3, pp. 62-68, 2014.

[8] I. G. N. A. Rajistha, D. A. K. Claria, A. A. I. M. Warmadewi, and I. G. A. A. D. Susanthi, "Keywords, lexical cohesive devices and the impact of search engine result for tour website," in Proceedings of International Conference of Social Science, ICOSS 2018, 2019.

[9] M. A. K. Halliday and R. Hasan, Cohesion in english. London: Longman Group Ltd, 1976.

[10] Gusti, G. Made, and K. Naya, "Lembongan: Snorkeling, Mangrove Forest, Devils Tear, 
Seaweed Farm, Goa Gala-Gala, Panorama Point.”

[11] Gusti, G. Made, and K. Naya, "Adventure: Big Discount for Bali Rafting Adventure.” .

[12] Gusti, G. Made, and K. Naya, "Full Day: Barong Dance, Ubud Monkey Forest, Kintamani Volcano, Tegalalang Rice Terrace, Tirta Empul.".

[13] Gusti, G. Made, and K. Naya, "Animal: Turtle Island, Bali Bird Park, Kemenuh Butterfly Park, Ubud Art Village.”.

[14] Gusti, G. Made, and K. Naya, "Full Day: Elephant Ride Bali, Tegalalang Rice Terrace (Swing), Ubud Monkey Forest, Coffee Plantation." .

[15] Gusti, G. Made, and K. Naya, “Activity: Bali Aero Fly Station (Sky Diving).”.

[16] Gusti, G. Made, and K. Naya, "Full Day: Kerta Gosa, Goa Lawah, Tirta Gangga, Lempuyang Temple.".

[17] Gusti, G. Made, and K. Naya, "Full Day: Elephant Ride Bali, Ubud Art Village, Tegenungan Waterfall, Batuan Temple.".

[18] Gusti, G. Made, and K. Naya, "Full Day: Bali Swing and Tegenungan Waterfall.".

[19] Gusti, G. Made, and K. Naya, "Full Day: Taman Ayun Temple, Ulun Danu Temple, Banjar Hot Spring, Buddhist Temple, Munduk Waterfall." .

[20] Gusti, G. Made, and K. Naya, "Full Day: Kintamani Cycling, Ubud Monkey Forest, Tegenungan Waterfall."

[21] Gusti, G. Made, and K. Naya, "Activity: Tanjung Benoa Water Sports Cheapest Prices." .

[22] Gusti, G. Made, and K. Naya, "Full Day: Kintamani Cycling, Taman Ayun Temple, Tanah Lot Sunset.".

[23] Gusti, G. Made, and K. Naya, "Bali SPA: Balinese Massage \& SPA in Jimbaran.”. 